\title{
Comparing State Portfolio Standards AND SYSTEM-BENEFITS CHARGES UNDER RESTRUCTURING
}

\author{
Ryan Wiser \\ Lawrence Berkeley National Laboratory \\ Kevin Porter \\ National Renewable Energy Laboratory \\ Mark Bolinger \\ Lawrence Berkeley National Laboratory
}

October 23, 2000

Table 1. RPS Policies Established at the State Level Under Restructuring

\begin{tabular}{|c|c|}
\hline State & Purchase Requirement \\
\hline Arizona & $\begin{array}{l}0.2 \% \text { in } 2001 \text {, rising by } 0.2 \% / y r \text { to } 1 \% \text { in } 2005 \text {, and to } 1.05 \% \text { in } 2006 \text {, then to } 1.1 \% \text { from } 2007 \text { to } \\
2012 \text {. Competitive retail suppliers are exempt until } 2004 \text {. Utility distribution companies may } \\
\text { recover costs of the RPS through reallocating existing SBC accounts for DSM and partly through } \\
\text { environmental portfolio surcharge. }\end{array}$ \\
\hline Connecticut & $\begin{array}{l}\text { Class I or II Technologies: } 5.5 \% \text { in } 2000,6 \% \text { in } 2005,7 \% \text { in } 2009 \text { and thereafter. Class I } \\
\text { Technologies: } 0.5 \% \text { in } 2000+0.25 \% / y r \text { to } 1 \% \text { in } 2002,6 \% \text { in } 2009 \text { and thereafter. Revised law in } \\
1999 \text { clarifies that standard is energy based, not capacity based and allows individual suppliers to } \\
\text { petition PUC for delay of RPS targets of up to } 2 \text { years. PUC has denied at least one petition for } \\
\text { delay. PUC has established that RPS shall not apply to standard offer service, but this decision is } \\
\text { under appeal }\end{array}$ \\
\hline Maine & $\begin{array}{l}30 \% \text { of retail sales in } 2000 \text { and thereafter as condition of licensing. PUC will revisit RPS within } 5 \\
\text { years after retail competition. PUC has proposed to eliminate RPS in favor of an SBC. }\end{array}$ \\
\hline Massachusetts & $\begin{array}{l}1 \% \text { of sales to end-use customers from new renewables in } 2003 \text { or } 1 \text { year after any renewable is } \\
\text { within } 10 \% \text { of average spot-market price, }+0.5 \% / y r \text { to } 4 \% \text { in } 2009 \text {, and }+1 \% / y r \text { increase thereafter } \\
\text { until date determined by Division of Energy Resources (DOER). Preliminary RPS design } \\
\text { proposal (June } 2000 \text { ) does not propose standard for existing renewables - DOER plans to monitor } \\
\text { market and adopt standard if there is significant attrition of renewables. }\end{array}$ \\
\hline Nevada & $\begin{array}{l}0.2 \% \text { of total Nevada consumption as of January } 1,2001 \text {. Increases by } 0.2 \% \text { biannually until } \\
\text { reaches } 1 \% .50 \% \text { of requirement from solar. Sierra Pacific given special treatment. Rural electric } \\
\text { coops, general improvement districts, and others are exempted. With retail competition delay, it is } \\
\text { also possible that RPS will be delayed. }\end{array}$ \\
\hline New Jersey & $\begin{array}{l}\text { Class I of II Technologies: } 2.5 \% \text { when BPU adopts interim standards with no sunset. Class I } \\
\text { Technologies: } 0.5 \% \text { in } 2001,1 \% \text { in } 2006,+0.5 \% / y \text { to } 4 \% \text { in } 2012 \text {. }\end{array}$ \\
\hline New Mexico & $\begin{array}{l}\text { Up to } 5 \% \text { for standard offer service by } 2002 \text { if it can be shown renewable resources are available } \\
\text { in New Mexico and if cost of standard offer service does not increase by more than } 1 \text { mill/kWh. } \\
\text { Purchase requirement could initially start at lower level if above conditions not met. }\end{array}$ \\
\hline Pennsylvania & $\begin{array}{l}\text { For PECO, West Penn, and PP\&L, } 20 \% \text { of residential consumers served by competitive default } \\
\text { provider: } 2 \% \text { in } 2001 \text {, rising } 0.5 \% / \text { year. For GPU, } 0.2 \% \text { in } 2001 \text { for } 20 \% \text { of customers, } 40 \% \text { of } \\
\text { customers in } 2002,60 \% \text { in } 2003,80 \% \text { in } 2004 \text { and thereafter. }\end{array}$ \\
\hline Texas & $\begin{array}{l}\text { Legislation establishes renewable energy capacity targets: } 1280 \mathrm{MW} \text { by } 2003 \text { increasing to } 2880 \\
\text { MW by } 2009 \text { ( } 880 \mathrm{MW} \text { of which is existing generation). RPS rule translates capacity targets into } \\
\text { percentage energy purchase requirements. }\end{array}$ \\
\hline Wisconsin & $0.5 \%$ by 2001 , increasing to $2.2 \%$ by 2011 ( $0.6 \%$ can come from facilities installed before 1998$)$. \\
\hline
\end{tabular}


Table 1. RPS Policies Established at the State Level Under Restructuring (continued)

\begin{tabular}{|c|c|c|}
\hline State & Resource Eligibility & Credit Trading \\
\hline Arizona & $\begin{array}{l}2001 \text { - at least } 50 \% \text { solar electric-remainder from } \\
\text { R\&D, solar hot water, or other in-state landfill gas, } \\
\text { wind and biomass. R\&D investments can reduce } \\
\text { RPS target by up to } 10 \% \\
2002-2003 \text { - same as } 2001 \text { except R\&D investments } \\
\text { can reduce RPS target by up to } 5 \% \\
2004-2012 \text { - at least } 60 \% \text { solar electric-remainder } \\
\text { from solar hot water and in-state landfill gas, wind } \\
\text { and biomass }\end{array}$ & To be determined \\
\hline Connecticut & $\begin{array}{l}\text { Class I: solar, wind, new sustainable biomass, landfill } \\
\text { gas, and fuel cells; Class II: licensed hydro, MSW, } \\
\text { other biomass }\end{array}$ & $\begin{array}{l}\text { Law allows suppliers to satisfy RPS by } \\
\text { participating in credit trading program } \\
\text { approved by the state, but state PUC has } \\
\text { indicated it has no plans to establish a } \\
\text { credit trading program; may allow private } \\
\text { actors to develop credit trading system }\end{array}$ \\
\hline Maine & $\begin{array}{l}\text { Fuel cells, tidal, solar, wind, geothermal, hydro, } \\
\text { biomass, and MSW (under } 100 \mathrm{MW} \text { ); high efficiency } \\
\text { cogeneration of any size; resource supply under this } \\
\text { definition far exceeds RPS-driven demand }\end{array}$ & $\begin{array}{l}\text { PUC decided against credit trading to } \\
\text { maintain consistency with regional } \\
\text { disclosure tracking systems }\end{array}$ \\
\hline Massachusetts & $\begin{array}{l}\text { Solar, wind, ocean thermal, wave, or tidal, fuel cells } \\
\text { using renewable fuels, landfill gas, waste-to-energy, } \\
\text { hydro, and low-emission, advanced biomass; waste- } \\
\text { to-energy and hydro cannot count toward new } \\
\text { standard; new renewables defined as those that begin } \\
\text { commercial operation or represent an increase in } \\
\text { capacity at an existing facility after December } 31 \text {, } \\
\text { 1997; DOER can add technologies after hearings }\end{array}$ & $\begin{array}{l}\text { Credit trading would require subsequent } \\
\text { legislative approval; DOER participating } \\
\text { in negotiations over the establishment of a } \\
\text { regional tradable certificates system }\end{array}$ \\
\hline Nevada & $\begin{array}{l}50 \% \text { from new solar electric or solar thermal that } \\
\text { offsets electric use; new defined as installed and } \\
\text { commenced operations after July 1, } 1997 ; 50 \% \text { from } \\
\text { wind, solar, geothermal, and biomass energy } \\
\text { resources in Nevada that are naturally regenerated }\end{array}$ & $\begin{array}{l}\text { Will be based on renewable energy } \\
\text { credits, if applicable; Commission } \\
\text { exploring adoption of credit trading } \\
\text { system }\end{array}$ \\
\hline New Jersey & $\begin{array}{l}\text { Class I: solar, PV, wind, fuel cells, geothermal, wave } \\
\text { or tidal, and methane gas from landfills or a biomass } \\
\text { facility, provided that the biomass is cultivated and } \\
\text { harvested in a sustainable manner; Class II: hydro } \\
\text { and resource recovery facilities in states with retail } \\
\text { competition; draft RPS rule would limit hydro to } \\
\text { under } 30 \mathrm{MW}\end{array}$ & $\begin{array}{l}\text { Electric suppliers may satisfy the RPS by } \\
\text { participating in a renewable energy credit } \\
\text { trading program approved by the Board of } \\
\text { Public Utilities (BPU); draft RPS rule } \\
\text { does not establish such a system }\end{array}$ \\
\hline New Mexico & $\begin{array}{l}\text { Wind, solar, geothermal, biomass, hydro, and fuel } \\
\text { cells }\end{array}$ & Not addressed \\
\hline Pennsylvania & Unspecified & Unspecified \\
\hline Texas & $\begin{array}{l}\text { Solar, wind, geothermal, hydro, wave, tidal, biomass, } \\
\text { biomass-based waste products, landfill gas }\end{array}$ & $\begin{array}{l}\text { Texas is first state to establish credit } \\
\text { trading program; ERCOT ISO selected as } \\
\text { the program administrator }\end{array}$ \\
\hline Wisconsin & $\begin{array}{l}\text { Wind, solar, biomass, geothermal, tidal, fuel cells that } \\
\text { use renewable fuel, hydro under } 60 \mathrm{MW} \text {; eligibility } \\
\text { may be expanded by PUC }\end{array}$ & $\begin{array}{l}\text { Legislation allows renewable purchases to } \\
\text { be satisfied through the purchase of } \\
\text { renewable energy credits; proposed rule } \\
\text { would reward credits for renewable } \\
\text { energy generation over RPS requirement }\end{array}$ \\
\hline
\end{tabular}


Table 1. RPS Policies Established at the State Level Under Restructuring (continued)

\begin{tabular}{|c|c|c|}
\hline State & Compliance Verification & Penalties \\
\hline Arizona & PUC order suggests a 12 month compliance period & $\begin{array}{l}30 \text { cents } / \mathrm{kWh} \text { starting in } 2004 \text {; proceeds go to } \\
\text { solar electric fund to finance solar facilities for } \\
\text { schools, cities, counties or state agencies }\end{array}$ \\
\hline Connecticut & $\begin{array}{l}\text { License application projection requirements; yearly } \\
\text { compliance periods beginning July 1; no later than } \\
\text { October } 1 \text { of each year, supplier must submit to DPUC } \\
\text { documentation demonstrating that the supplier complied } \\
\text { with the RPS in the previous } 12 \text { months based on } \\
\text { information from the ISO and that no 'double counting' } \\
\text { has occurred }\end{array}$ & $\begin{array}{l}\text { Must meet RPS to be licensed; flexible } \\
\text { penalties for failing to comply with license } \\
\text { conditions include license revocation or } \\
\text { suspension, a prohibition from accepting new } \\
\text { customers, or civil penalties }\end{array}$ \\
\hline Maine & $\begin{array}{l}\text { Must be met over 12-month periods; general description } \\
\text { of how RPS will be met at licensing; supplier files annual } \\
\text { report by May } 1 \text { of each year demonstrating compliance } \\
\text { for previous year and that no "double counting" has } \\
\text { occurred; leaves flexibility in amount and type of } \\
\text { information required and puts burden on supplier; may } \\
\text { consider certified audit as a form of compliance at a later } \\
\text { date; requires officer certification that RPS has been met } \\
\text { and that renewables have not been "double counted"; } \\
\text { Commission may conduct periodic audits to verify } \\
\text { compliance }\end{array}$ & $\begin{array}{l}\text { Variety of possible sanctions at discretion of } \\
\text { Commission including license revocation, } \\
\text { monetary penalties, and other appropriate } \\
\text { penalties; allows voluntary payment into } \\
\text { renewables R\&D fund to avoid license } \\
\text { revocation }\end{array}$ \\
\hline Massachusetts & $\begin{array}{l}\text { Legislation and DOER contemplate } 12 \text {-month } \\
\text { compliance period; DOER working on regional tradable } \\
\text { certificates system that would help determine RPS } \\
\text { compliance; retail supplier must submit annual report to } \\
\text { DOER demonstrating compliance }\end{array}$ & $\begin{array}{l}\text { DOER has considered multiple possible } \\
\text { penalties for non-compliance, but no decisions } \\
\text { have yet been made; imposition of penalties } \\
\text { may require subsequent legislative approval, } \\
\text { but DOER considering imposition of financial } \\
\text { sanctions through arrangement with PUC; } \\
\text { penalty could be set at three times average } \\
\text { market value of new renewables generation, or } \\
\text { at a fixed amount that may be periodically } \\
\text { revised by DOER }\end{array}$ \\
\hline Nevada & $\begin{array}{l}\text { At end of each calendar year, each supplier must submit } \\
\text { report to Commission to verify compliance }\end{array}$ & $\begin{array}{l}\text { Compliance required to maintain license; } \\
\text { penalties include license suspension and } \\
\text { revocation; exploring other approaches }\end{array}$ \\
\hline New Jersey & $\begin{array}{l}\text { Not addressed in legislation, but draft rule would apply } \\
12 \text {-month compliance period; compliance filings due } \\
\text { April } 1 \text { for previous year, with independent verification } \\
\text { from an auditor }\end{array}$ & $\begin{array}{l}\text { Draft RPS rule would require non-complying } \\
\text { retailers to purchase the required amount of } \\
\text { renewables and possibly face financial penalties } \\
\text { and/or license revocation or suspension }\end{array}$ \\
\hline New Mexico & To be determined & Not addressed \\
\hline Pennsylvania & Unspecified & Unspecified \\
\hline Texas & $\begin{array}{l}\text { Yearly compliance filings, with 3-month settlement } \\
\text { period at end of compliance year; RPS rule establishes } \\
\text { the ERCOT ISO to run renewable energy credit registry } \\
\text { to track and verify renewable energy credit transactions }\end{array}$ & $\begin{array}{l}\text { Penalty for noncompliance is the lesser of } 5 \\
\text { cents } / \mathrm{kWh} \text { or } 200 \% \text { of the average market value } \\
\text { of renewable energy credits; under certain } \\
\text { circumstances, penalty may not be assessed }\end{array}$ \\
\hline Wisconsin & $\begin{array}{l}\text { Yearly compliance filings with } 3 \text {-month settlement period } \\
\text { at end of each compliance year; compliance filings due } \\
\text { April } 15 \text {; total retail sales determined by calculating a 3- } \\
\text { year rolling average of an electric power provider's retail } \\
\text { sales }\end{array}$ & $\begin{array}{l}\text { Penalty of } \$ 5,000-\$ 500,000 \text { is allowed in } \\
\text { legislation }\end{array}$ \\
\hline
\end{tabular}


Table 1. RPS Policies Established at the State Level Under Restructuring (continued)

\begin{tabular}{|c|c|c|c|}
\hline State & Cost Cap & Credit Multipliers & $\begin{array}{c}\text { Out of State } \\
\text { Renewable Eligibility }\end{array}$ \\
\hline Arizona & $\begin{array}{l}\text { No explicit cap but } \\
\text { penalty acts as de facto } \\
\text { cap }\end{array}$ & $\begin{array}{l}\text { Various multipliers for early } \\
\text { installation before } 2003 \text {; in-state } \\
\text { installation or content; distributed } \\
\text { solar; net metering; and utility } \\
\text { green pricing programs; credit } \\
\text { multipliers are additive, to } \\
\text { maximum of } 2.0 \text { through } 2003 \text {; } \\
\text { retail provider can offset } 1 / 2 \text { of RPS } \\
\text { requirement in } 2001,1 / 4 \text { of } \\
\text { requirement in } 2002 \text { and } 2003 \text { if } \\
\text { they invest in Arizona solar } \\
\text { manufacturing facility. }\end{array}$ & $\begin{array}{l}\text { Out-of-state solar appears } \\
\text { eligible; landfill gas, wind } \\
\text { and biomass must be in- } \\
\text { state }\end{array}$ \\
\hline Connecticut & No explicit cap & None & Eligible \\
\hline Maine & $\begin{array}{l}\text { No explicit cap but } \\
\text { penalty and flexibility } \\
\text { conditions should reduce } \\
\text { cost fluctuations }\end{array}$ & None & $\begin{array}{l}\text { Eligible; energy must be } \\
\text { delivered to the ISO-NE } \\
\text { control area and meet load } \\
\text { in New England, or may in } \\
\text { any way satisfy load within } \\
\text { the ISO-NE control area } \\
\text { (for generation under } 5 \\
\text { MW); same provisions for } \\
\text { the Maritimes control area }\end{array}$ \\
\hline Massachusetts & $\begin{array}{l}\text { Not included in } \\
\text { legislation; DOER not } \\
\text { inclined to include }\end{array}$ & None & Eligible \\
\hline Nevada & $\begin{array}{l}\text { Not included in } \\
\text { legislation }\end{array}$ & None & Not eligible \\
\hline New Jersey & $\begin{array}{l}\text { None included in } \\
\text { legislation or draft rule }\end{array}$ & None & $\begin{array}{l}\text { Eligible generally; Class II } \\
\text { technologies must come } \\
\text { from states open to retail } \\
\text { competition }\end{array}$ \\
\hline New Mexico & $\begin{array}{l}\text { Overall cap on cost of } \\
\text { RPS of } 1 \mathrm{mill} / \mathrm{kWh}\end{array}$ & None & Not eligible \\
\hline Pennsylvania & $\begin{array}{l}\text { None included in } \\
\text { legislation }\end{array}$ & Unspecified & Unspecified \\
\hline Texas & $\begin{array}{l}\text { None explicit, but } \\
\text { implicit cap of } 5 \\
\text { cents/kWh for renewable } \\
\text { energy credits }\end{array}$ & None & $\begin{array}{l}\text { Not eligible unless } \\
\text { dedicated transmission line } \\
\text { into the state }\end{array}$ \\
\hline Wisconsin & None & None & Eligible \\
\hline
\end{tabular}


Table 1. RPS Policies Established at the State Level Under Restructuring (continued)

\begin{tabular}{|c|c|c|c|c|}
\hline State & $\begin{array}{l}\text { Company- or } \\
\text { Product-Based }\end{array}$ & $\begin{array}{c}\text { Treatment of } \\
\text { Hybrid } \\
\text { Generators } \\
\end{array}$ & $\begin{array}{c}\text { Solar Thermal } \\
\text { Eligibility }\end{array}$ & Self-Generation \\
\hline Arizona & Company-based & Not determined yet & Yes & Yes, for solar \\
\hline Connecticut & Company-based & $\begin{array}{l}\text { Not entirely clear; } \\
\text { probably only } \\
\text { renewables-portion } \\
\text { eligible }\end{array}$ & No & $\begin{array}{l}\text { No provisions in } \\
\text { legislation; RPS rule } \\
\text { would seem to } \\
\text { preclude; possibly } \\
\text { eligible if credit } \\
\text { trading system } \\
\text { developed }\end{array}$ \\
\hline Maine & $\begin{array}{l}\text { Revision to law in } \\
\text { May } 1999 \text { makes } \\
\text { standard effectively } \\
\text { product-based }\end{array}$ & $\begin{array}{l}\text { Only qualified } \\
\text { renewable and } \\
\text { cogen output are } \\
\text { eligible from multi- } \\
\text { fuel facilities }\end{array}$ & No & Not eligible \\
\hline Massachusetts & $\begin{array}{l}\text { Legislation may } \\
\text { imply company-based } \\
\text { but DOER also } \\
\text { considering product- } \\
\text { based }\end{array}$ & $\begin{array}{l}\text { Not entirely clear; } \\
\text { DOER proposal is } \\
\text { for renewables- } \\
\text { portion to be } \\
\text { eligible }\end{array}$ & No & $\begin{array}{l}\text { No provisions in } \\
\text { legislation; DOER is } \\
\text { advocating eligibility } \\
\text { of self-generation in } \\
\text { tradable certificates } \\
\text { system }\end{array}$ \\
\hline Nevada & $\begin{array}{l}\text { Not addressed though } \\
\text { legislation may imply } \\
\text { company-based }\end{array}$ & $\begin{array}{l}\text { Not yet addressed; } \\
\text { assume that only } \\
\text { renewable-fraction } \\
\text { qualifies }\end{array}$ & Yes & $\begin{array}{l}\text { Issue being explored } \\
\text { by Commission; } \\
\text { seems likely to be } \\
\text { inclusive }\end{array}$ \\
\hline New Jersey & $\begin{array}{l}\text { Legislation may } \\
\text { imply company-based } \\
\text { but not yet decided }\end{array}$ & $\begin{array}{l}\text { Not entirely clear; } \\
\text { probably only } \\
\text { renewables-portion } \\
\text { eligible }\end{array}$ & No & $\begin{array}{l}\text { No provisions in } \\
\text { legislation; draft } \\
\text { RPS rule would } \\
\text { seem to preclude; } \\
\text { possibly eligible if } \\
\text { credit trading system } \\
\text { developed }\end{array}$ \\
\hline New Mexico & $\begin{array}{l}\text { Product-based; } \\
\text { utilities can offer } \\
\text { renewable energy } \\
\text { tariff but cannot } \\
\text { count these sales } \\
\text { towards } 5 \% \text { standard }\end{array}$ & Not addressed & Not addressed & Not addressed \\
\hline Pennsylvania & Unspecified & Unspecified & Unspecified & Unspecified \\
\hline Texas & Company-based & $\begin{array}{l}\text { Not eligible unless } \\
\text { solar hybrid (then } \\
\text { only renewables } \\
\text { fraction is eligible) }\end{array}$ & $\begin{array}{l}\text { Eligible if meets } \\
\text { metering } \\
\text { requirements }\end{array}$ & $\begin{array}{l}\text { Eligible if meets } \\
\text { metering } \\
\text { requirements }\end{array}$ \\
\hline Wisconsin & $\begin{array}{l}\text { Legislation may } \\
\text { imply company-based }\end{array}$ & $\begin{array}{l}\text { Renewables } \\
\text { portion is eligible }\end{array}$ & No & $\begin{array}{l}\text { Legislation does not } \\
\text { specify, but would } \\
\text { appear to preclude }\end{array}$ \\
\hline
\end{tabular}


Table 1. RPS Policies Established at the State Level Under Restructuring (continued)

\begin{tabular}{|c|c|c|}
\hline State & Additional Flexibility Mechanisms & Status \\
\hline Arizona & $\begin{array}{l}\text { Waivers; use of SBC funds for RPS } \\
\text { compliance costs; credit multipliers; utility } \\
\text { distribution companies without a renewable } \\
\text { energy program may request a waiver because } \\
\text { of "extreme circumstances" }\end{array}$ & $\begin{array}{l}\text { Commission order in April 2000; rulemaking later } \\
\text { in 2000; comprehensive review of policy in } 2003 \\
\text { to determine RPS status and level from } 2004 \\
\text { onward }\end{array}$ \\
\hline Connecticut & $\begin{array}{l}\text { Other approaches to verifying compliance may } \\
\text { be accepted by PUC; } 2 \text { year delay of } \\
\text { compliance may be requested }\end{array}$ & $\begin{array}{l}\text { Restructuring legislation in 1998; licensing } \\
\text { regulations in } 1998 \text { established certain RPS } \\
\text { provisions; revisions to law in 1999; RPS begins } \\
\text { July 1, 2000 }\end{array}$ \\
\hline Maine & $\begin{array}{l}\text { If service begins less than } 6 \text { months prior to } \\
\text { December } 31 \text {, compliance period extends } \\
\text { beyond the year to the second December } 31 \text {; } \\
\text { advisory ruling provision allows interested } \\
\text { parties to request ruling on whether a particular } \\
\text { facility satisfies the eligibility requirements; } \\
\text { extra year "cure period" for suppliers that } \\
\text { obtain } 20 \% \text { - } 30 \% \text { of eligible resources; } \\
\text { Commission may extend cure period for those } \\
\text { who can demonstrate an ownership interest or } \\
\text { entitlement in an eligible new facility that will } \\
\text { come on line within } 2 \text { years; can waive all } \\
\text { penalties with a showing that a supplier could } \\
\text { not meet RPS because of market conditions }\end{array}$ & $\begin{array}{l}\text { Restructuring legislation in 1997; PUC worked out } \\
\text { design details in 1998; revisions to RPS law in } \\
\text { May 1999; RPS took effect March 1, 2000; PUC } \\
\text { considering proposing legislation to drop RPS in } \\
\text { favor of SBC }\end{array}$ \\
\hline Massachusetts & $\begin{array}{l}\text { DOER considering multiple flexibility } \\
\text { mechanisms, including allowance for early } \\
\text { compliance, credit banking, 3-month } \\
\text { settlement period at end of each compliance } \\
\text { period, etc. }\end{array}$ & $\begin{array}{l}\text { Restructuring legislation in } 1997 \text {; DOER released } \\
\text { preliminary proposal in June } 2000 \text { but working on } \\
\text { regional tradable certificates program; new RPS } \\
\text { begins in } 2003\end{array}$ \\
\hline Nevada & $\begin{array}{l}\text { None established yet; issue being explored by } \\
\text { Commission }\end{array}$ & $\begin{array}{l}\text { Restructuring legislation in 1997; PUC undertakes } \\
\text { RPS investigation in 1999; PUC workshop and } \\
\text { hearing in October 2000; investigation not yet } \\
\text { complete; RPS slated to begin in } 2001\end{array}$ \\
\hline New Jersey & $\begin{array}{l}\text { None proposed in legislation; draft rule applies } \\
\text { flexible penalties for non-compliance }\end{array}$ & $\begin{array}{l}\text { Restructuring legislation in 1999; draft RPS rule in } \\
\text { late 1999; final rule not yet released; RPS begins } \\
\text { in 2001, at latest }\end{array}$ \\
\hline New Mexico & $\begin{array}{l}\text { RPS may be reduced if there are not enough } \\
\text { renewable energy resources in the state; costs } \\
\text { of standard offer service cannot increase by } \\
\text { more than } 1 \mathrm{mill} / \mathrm{kWh}\end{array}$ & $\begin{array}{l}\text { PUC order in May 2000; modified September } \\
2000 \text { to include cost cap; restructuring delayed } \\
\text { until } 2002\end{array}$ \\
\hline Pennsylvania & Unspecified & $\begin{array}{l}\text { Legislation in 1996; individual utility settlements } \\
\text { in } 1998\end{array}$ \\
\hline Texas & $\begin{array}{l}\text { Two year banking of renewable energy credits } \\
\text { allowed; limited deficit banking also allowed } \\
\text { in first } 2 \text { years; } 3 \text { month settlement period at } \\
\text { end of each compliance year in which to } \\
\text { purchase needed credits }\end{array}$ & $\begin{array}{l}\text { Restructuring legislation in } 1999 \text {; final RPS rule } \\
\text { complete in 12/99; credit trading protocol being } \\
\text { designed and implemented; RPS begins in } 2002 \text {, } \\
\text { with early compliance beginning in mid } 2001\end{array}$ \\
\hline Wisconsin & $\begin{array}{l}\text { Three month settlement period; total retail } \\
\text { sales determined by calculating a 3-year rolling } \\
\text { average of an electric power provider's retail } \\
\text { sales; credit banking is allowed; unlimited } \\
\text { credit life until claimed }\end{array}$ & $\begin{array}{l}\text { RPS legislation established as part of state budget } \\
\text { within a wholesale electricity reform measure in } \\
\text { late 1999; proposed regulations subject of PUC } \\
\text { hearing in July } 2000\end{array}$ \\
\hline
\end{tabular}


Table 2. SBC Policies Established at the State Level Under Restructuring

\begin{tabular}{|c|c|c|}
\hline State & Level of Funding & Resource Eligibility \\
\hline California & $\begin{array}{l}\$ 135 \text { million/year for } 4 \text { years beginning } 1998 ; \\
\text { additional funds provided for renewable energy } \\
\text { R\&D; fund extended at } \$ 135 \text { million/year adjusted } \\
\text { for inflation and load growth through } 2012\end{array}$ & $\begin{array}{l}\text { Non-utility, in-state solar, wind, biomass, } \\
\text { geothermal, MSW, and small hydro (less than or } \\
\text { equal to } 30 \mathrm{MW} \text { ) }\end{array}$ \\
\hline Connecticut & $\begin{array}{l}\text { Approx. } \$ 14 \text { million/year in } 2000 ; \$ 30 \text { million/year } \\
\text { in } 2004 \text { and thereafter }\end{array}$ & $\begin{array}{l}\text { Wind, solar, fuel cells, ocean, landfill gas and low- } \\
\text { emission advanced biomass technologies. }\end{array}$ \\
\hline Delaware & $\begin{array}{l}\text { About } \$ 1.5 \text { million/year for energy efficiency, with } \\
\text { unspecified amount for renewables }\end{array}$ & To be determined \\
\hline $\begin{array}{l}\text { Illinois Fund \#1 } \\
\text { (statewide) }\end{array}$ & $\$ 5$ million/year for 10 years beginning in 1999 & $\begin{array}{l}\text { Wind, solar thermal, PV, dedicated crop biomass } \\
\text { and organic waste biomass, retrofit or expansion of } \\
\text { existing hydro }\end{array}$ \\
\hline Massachusetts & $\begin{array}{l}\text { Averages } \$ 45 \text { million/year for first } 5 \text { years, with } \\
\text { roughly } \$ 10 \text { million/year for pollution controls, debt } \\
\text { service, or retirement for waste-to-energy facilities; } \\
\text { continues at average of } \$ 25 \text { million/year with no } \\
\text { support for waste-to-energy }\end{array}$ & $\begin{array}{l}\text { New solar, wind, ocean, advanced biomass, fuel } \\
\text { cells; limited eligibility for waste-to-energy for first } \\
\text { five years }\end{array}$ \\
\hline Montana & $\begin{array}{l}\text { \$14 million/year for efficiency, renewables, and } \\
\text { R\&D from 1999-2003, at which point level will be } \\
\text { re-evaluated; perhaps } \$ 2 \text { million per year will be } \\
\text { dedicated to renewables }\end{array}$ & $\begin{array}{l}\text { Renewable generators constructed after January } 1 \text {, } \\
1999\end{array}$ \\
\hline New Jersey & $\begin{array}{l}\text { Approx. } \$ 32 \text { million from } 2000-2007 \text { with review } \\
\text { after } 8 \text { years }\end{array}$ & $\begin{array}{l}\text { Solar, wind, fuel cells, geothermal, wave or tidal, } \\
\text { and methane gas or a biomass facility, provided that } \\
\text { the biomass is cultivated and harvested in a } \\
\text { sustainable manner }\end{array}$ \\
\hline New Mexico & $\begin{array}{l}\$ 4 \text { million/year for renewables beginning in } 2001 \text {; } \\
\text { no definite expiration date, although restructuring } \\
\text { law contemplates a revisiting of support for } \\
\text { renewables at some later date }\end{array}$ & $\begin{array}{l}\text { Solar, wind, hydro, geothermal, landfill gas, } \\
\text { anaerobic digesters, and biomass-based fuel cells }\end{array}$ \\
\hline New York & $\begin{array}{l}\$ 17 \text { million over three years for renewables, from } \\
1999 \text { through 2001; proposal to extend and increase } \\
\text { funding level for } 5 \text { years }\end{array}$ & Wind, solar, biomass \\
\hline Oregon & $\$ 8.7$ million annually for 10 years beginning in 2001 & $\begin{array}{l}\text { Wind, waste, solar, geothermal, landfill gas, digester } \\
\text { gas, energy crops, low-emission biomass based on } \\
\text { solid organic fuels, and hydro facilities outside } \\
\text { protected federal areas }\end{array}$ \\
\hline Pennsylvania & $\begin{array}{l}\text { PECO, PP\&L, GPU, and West Penn settlements total } \\
\text { approx. } \$ 55 \text { million over } 5 \text { years, used for } \\
\text { renewables, clean energy, energy efficiency and } \\
\text { economic development that promotes clean energy; } \\
\text { total renewables funding of perhaps } \$ 5 \text { million per } \\
\text { year; PECO/Unicom merger will result in another } \\
\$ 20 \text { million added to PECO SBC fund (see Table 3); } \\
\text { renewable Energy Pilot Fund for low income } \\
\text { customers raises } \$ 3.9 \text { million/year for } 2001-2002\end{array}$ & $\begin{array}{l}\text { PECO, PP\&L, GPU, and West Penn funds not } \\
\text { specific; Renewable Energy Pilot Fund mostly } \\
\text { focused on solar (PV and hot water); one utility } \\
\text { (West Penn) has proposal for small wind program }\end{array}$ \\
\hline Rhode Island & $\begin{array}{l}\text { Approx. } \$ 2 \text { million/year for renewables from 1997- } \\
2001 ; \text { reevaluate need for and size of SBC after } 2001\end{array}$ & $\begin{array}{l}\text { Wind, solar, sustainable biomass, small hydro under } \\
100 \text { MW that does not require new dams }\end{array}$ \\
\hline Wisconsin & $\begin{array}{l}\text { Approx. } \$ 3 \text { million per year; sunset review } \\
\text { scheduled for } 2004 \text { or } 2005\end{array}$ & $\begin{array}{l}\text { Eligible technologies include solar thermal, } \\
\text { photovoltaics, wind, geothermal, biomass, fuel cells } \\
\text { powered by renewables, and hydro under } 60 \mathrm{MW} \text {; } \\
\text { intends to focus on customer-side applications }\end{array}$ \\
\hline
\end{tabular}


Table 2. SBC Policies Established at the State Level Under Restructuring (continued)

\begin{tabular}{|c|c|c|}
\hline State & Fund Distribution & Administration \\
\hline California & $\begin{array}{l}\text { For first } 4 \text { years: } 45 \% \text { used to support existing renewables; } 30 \% \text { to support new } \\
\text { renewables; } 10 \% \text { to support solar and other emerging renewables; } 15 \% \text { to support } \\
\text { green power market; distribution for } 10 \text { year extension not yet determined }\end{array}$ & California Energy Commission \\
\hline Connecticut & $\begin{array}{l}\text { Grants, direct or equity investments, contracts or other action that support } \\
\text { research, development, manufacture, commercialization, deployment and } \\
\text { installation of renewable technologies, and action that expand renewable expertise } \\
\text { of individuals, businesses, and lending institutions; thus far, the fund is taking a } \\
\text { venture-capital-like investment approach }\end{array}$ & Connecticut Innovations, Incorporated \\
\hline Delaware & To be determined & $\begin{array}{l}\text { Delaware Development Office, with } \\
\text { assistance from state consumer } \\
\text { advocate and energy office }\end{array}$ \\
\hline $\begin{array}{l}\text { Illinois Fund } \\
\# 1 \text { (statewide) }\end{array}$ & $\begin{array}{l}\text { Legislation allows grants, loans, and rebates, but the fund administrator so far has } \\
\text { employed only grants and rebates }\end{array}$ & $\begin{array}{l}\text { Illinois Department of Commerce and } \\
\text { Community Affairs }\end{array}$ \\
\hline Massachusetts & $\begin{array}{l}\text { Will focus on distributed generation, the competitive green power market, the } \\
\text { renewable energy business sector, green buildings, and helping educational } \\
\text { institutions develop renewable energy programs }\end{array}$ & $\begin{array}{l}\text { Massachusetts Technology } \\
\text { Collaborative }\end{array}$ \\
\hline Montana & $\begin{array}{l}\text { Utilities receive credit against SBC allocation for expenses on covered programs } \\
\text { under the SBC; state administers remaining funds; large customers with loads of } \\
\text { more than } 1 \mathrm{MW} \text { must dedicate } 0.9 \text { mills } / \mathrm{kWh} \text {, or } \$ 500,000 \text {, minus any amount } \\
\text { they spend directly on energy efficiency or renewable energy }\end{array}$ & $\begin{array}{l}\text { Utilities and large industrials, with } \\
\text { remaining funds administered by state }\end{array}$ \\
\hline New Jersey & $\begin{array}{l}\text { Board of Public Utilities, in consultation with the Department of Environmental } \\
\text { Protection, will determine fund distribution and allocation; BPU is considering } \\
\text { two competing proposals, both generally modeled after California's SBC program }\end{array}$ & $\begin{array}{l}\text { Board of Public Utilities governs } \\
\text { program; detailed administration not } \\
\text { determined }\end{array}$ \\
\hline New Mexico & $\begin{array}{l}\text { Half of funds to be distributed to solar and half to a bidding process for other } \\
\text { renewables; funding recipients are limited to school districts and the governing } \\
\text { entities of cities, towns, villages or counties }\end{array}$ & To be determined \\
\hline New York & $\begin{array}{l}\text { Funds competitively bid in technology-specific solicitations; co-funding of } 50 \% \\
\text { or more is required; three wind projects totaling } 27 \mathrm{MW} \text { in various stages of } \\
\text { development; Niagara Mohawk has funded a fourth wind project with its own } \\
\text { SBC funds; up to } 300 \mathrm{PV} \text { projects will be installed ( }>1 \mathrm{MW} \text { total), as well as co- } \\
\text { firing of willow trees in a coal-fired plant }\end{array}$ & $\begin{array}{l}\text { New York State Energy Research and } \\
\text { Development Authority (NYSERDA) }\end{array}$ \\
\hline Oregon & $\begin{array}{l}\text { Not yet determined; preliminary ideas include a wind RFP and a customer credit } \\
\text { on green power options }\end{array}$ & $\begin{array}{l}\text { A new nonprofit organization will be } \\
\text { created to run the program }\end{array}$ \\
\hline Pennsylvania & $\begin{array}{l}\text { PECO Fund has invested in green townhouse development, Energy } \\
\text { Unlimited/Community Energy wind project, geothermal heat pump installation, } \\
\text { and a manufacturer of PV-powered traffic control equipment, and has developed } \\
\text { an unsecured consumer loan product for PV, solar hot water, fuel cells, } \\
\text { geothermal heat pumps, and energy efficiency } \\
\text { Renewable Energy Pilot Fund mostly dedicated to PV and solar hot water } \\
\text { systems, although small wind systems are an eligible technology in West Penn's } \\
\text { program }\end{array}$ & $\begin{array}{l}\text { PECO: The Reinvestment Fund } \\
\text { GPU/Penelec: The Community } \\
\text { Foundation of the Alleghenies } \\
\text { GPU/MetEd: Berks County } \\
\text { Community Foundation } \\
\text { PP\&L: The Sustainable Energy Fund } \\
\text { West Penn: not yet determined }\end{array}$ \\
\hline Rhode Island & $\begin{array}{l}\text { Funds renewable projects and programs through RFP process; funded resource } \\
\text { studies in 1997; in 1998-2000, supported wind investigations, fuel cells, and PV } \\
\text { projects; currently reassessing program and funding strategy in renewable energy }\end{array}$ & $\begin{array}{l}\text { Rhode Island Renewable Energy } \\
\text { Collaborative (RIREC) with oversight } \\
\text { from state PUC }\end{array}$ \\
\hline Wisconsin & $\begin{array}{l}\text { Details not yet determined; grant solicitations are likely; focus will be on } \\
\text { customer-sited generation with a business development and educational focus }\end{array}$ & $\begin{array}{l}\text { Non-profit administrator will be } \\
\text { selected to run the program }\end{array}$ \\
\hline
\end{tabular}


Table 2. SBC Policies Established at the State Level Under Restructuring (continued)

\begin{tabular}{|c|c|}
\hline State & Status \\
\hline California & $\begin{array}{l}\text { Legislation in 1996. Fund distribution finalized in 1997; funds collected and distributed } \\
\text { beginning } 1998 \text {. Existing Account is supporting } 259 \text { facilities and } 4000 \mathrm{MW} \text {. Bids for New } \\
\text { Account incentive resulted in } 55 \text { projects and over } 550 \mathrm{MW} \text {. Eleven projects are on-line ( } 8 \\
\text { landfill gas, } 2 \text { wind, one geothermal). The CEC estimates that } 13 \text { projects will come on-line in } \\
2000 \text { and another } 29 \text { in } 2001 \text {. Three projects (one wood residue, two landfill gas) have been } \\
\text { cancelled. Emerging Account has resulted in } 239 \text { small projects (mostly PV) for total capacity of } \\
1.24 \mathrm{MW} \text {, with another } 1.44 \mathrm{MW} \text { in various stages of planning and development. Legislation } \\
\text { signed in September } 2000 \text { extended the SBC fund for } 10 \text { years. }\end{array}$ \\
\hline Connecticut & $\begin{array}{l}\text { Legislation in 1998. Made first investment of } \$ 500,000 \text { in March } 2000 \text { to the Connecticut } \\
\text { Energy Co-op, a green power marketer that will also support the installation of home PV or solar } \\
\text { thermal systems. Second investment in August } 2000 \text { to Solar Dynamics, Inc. to sell portable PV } \\
\text { power generators (a spin-off of ASE Americas' Solar Power Companion product line). Also } \\
\text { exploring on- and off-shore wind, fuel cells, and landfill gas. }\end{array}$ \\
\hline Delaware & Fund collection began in October 1999. Implementation efforts just getting underway. \\
\hline $\begin{array}{l}\text { Illinois Fund \#1 } \\
\text { (statewide) }\end{array}$ & $\begin{array}{l}\text { Legislation in 1997. Fund collection started in } 1998 \text { and distribution began in 1999. Has funded } \\
\text { a number of PV systems of various sizes, mostly on commercial and community buildings. Has } \\
\text { also funded a landfill gas project, and a few small solar thermal projects. }\end{array}$ \\
\hline Massachusetts & $\begin{array}{l}\text { Legislation in 1997. Distribution was on hold until lawsuit was resolved. Court ruled in favor of } \\
\text { state in April 2000. Strategic plan released in June 2000. Currently working on a detailed } \\
\text { operating plan. No projects have yet been funded. }\end{array}$ \\
\hline Montana & $\begin{array}{l}\text { Montana Power Company released wind RFP in } 2000 \text { and has approved a production incentive } \\
\text { for } 3 \text { MW of a } 23 \text { MW project. MPC is also working with local non-profits and industry } \\
\text { participants on several PV initiatives focused on demonstration projects. Rural cooperatives and } \\
\text { Montana Dakota Utilities just getting started. }\end{array}$ \\
\hline New Jersey & $\begin{array}{l}\text { Legislation in 1999. NJ Board of Public Utilities considering two different fund proposals. One } \\
\text { is from NRDC and six of the state's seven electric utilities; the other from the New Jersey } \\
\text { Division of Ratepayer Advocates and several other public interest groups. }\end{array}$ \\
\hline New Mexico & Rulemaking just getting underway. \\
\hline New York & $\begin{array}{l}\text { PUC decision in 1998. Four wind projects over } 30 \mathrm{MW} \text { in various stages of planning. Also } \\
\text { sponsoring wind resource RFP; rooftop and commercial PV ( }>1 \mathrm{MW} \text { total); and willow project } \\
\text { for biomass co-firing. NYSERDA proposal to extend and increase SBC fund for } 5 \text { years. }\end{array}$ \\
\hline Oregon & $\begin{array}{l}\text { Legislation in 1999. Oregon PUC staff proposed draft rules in April } 2000 \text { for collecting SBC } \\
\text { funds. Separately, a task force of state agencies and interested stakeholders has explored } \\
\text { program administration and implementation issues with the PUC. In July } 2000 \text { PUC staff } \\
\text { released a draft white paper outlining the structure of a new non-profit entity to administer the } \\
\text { fund. }\end{array}$ \\
\hline Pennsylvania & $\begin{array}{l}\text { Legislation in 1996. Individual utility settlements in } 1998 \text {. Only PECO fund is active, having } \\
\text { invested } \$ 1.7 \text { million through July } 2000 \text {. PECO/Unicom merger will add } \$ 20 \text { million to PECO } \\
\text { fund. (see Table 3). }\end{array}$ \\
\hline Rhode Island & $\begin{array}{l}\text { Legislation in 1996. Some PV projects have been sponsored. Planned wind project failed to } \\
\text { materialize because of poor economics and difficulties in acquiring a site. One fuel cell installed. } \\
\text { Currently developing new programs. }\end{array}$ \\
\hline Wisconsin & $\begin{array}{l}\text { Legislation in 1999. Wisconsin Department of Administration must select non-profit } \\
\text { administrator(s) and establish requirements and grant applications procedures. }\end{array}$ \\
\hline
\end{tabular}


Table 3. Other State Renewable Energy Funds Established Under Other Mechanisms Related to Restructuring (Utility Mergers, State Legislation, etc.)

\begin{tabular}{|c|c|c|c|c|c|}
\hline State & Level of Funding & $\begin{array}{l}\text { Resource } \\
\text { Eligibility }\end{array}$ & $\begin{array}{c}\text { Fund } \\
\text { Distribution }\end{array}$ & Administration & Status/Other \\
\hline $\begin{array}{l}\text { Illinois Fund \#2 } \\
\text { (Commonwealth } \\
\text { Edison) }\end{array}$ & $\begin{array}{l}\text { \$225 million; unspecified } \\
\text { amount for renewable } \\
\text { energy; in addition to } \\
\text { renewables and energy } \\
\text { efficiency, funds can also } \\
\text { be used to support other } \\
\text { energy-related programs } \\
\text { that improve Illinois' } \\
\text { environmental quality, } \\
\text { wildlife habitat and natural } \\
\text { areas preservation, the } \\
\text { Illinois Citizens Utility } \\
\text { Board, and clean coal } \\
\text { initiatives }\end{array}$ & $\begin{array}{l}\text { Clean energy } \\
\text { technologies } \\
\text { include solar, } \\
\text { wind, } \\
\text { biomass, and } \\
\text { energy } \\
\text { efficiency } \\
\text { programs that } \\
\text { reduce } \\
\text { electricity } \\
\text { consumption } \\
\text { and prevent } \\
\text { pollution }\end{array}$ & $\begin{array}{l}\text { TBD, but } \\
\text { preliminary } \\
\text { indications are } \\
\text { that it will } \\
\text { provide venture } \\
\text { capital support, } \\
\text { grants, loans, } \\
\text { and other } \\
\text { incentives to } \\
\text { projects that } \\
\text { encourage the } \\
\text { development of } \\
\text { clean energy } \\
\text { technologies }\end{array}$ & $\begin{array}{l}\text { Illinois Clean Energy } \\
\text { Community } \\
\text { Foundation }\end{array}$ & $\begin{array}{l}\text { Trustees have been appointed; } \\
\text { program and grant guidelines } \\
\text { expected by summer } 2000\end{array}$ \\
\hline $\begin{array}{l}\text { Illinois Fund \#3 } \\
\text { (City of } \\
\text { Chicago) }\end{array}$ & $\begin{array}{l}\$ 100 \text { million over four } \\
\text { years, created as part of a } \\
\text { resolution to a franchise } \\
\text { dispute with } \\
\text { Commonwealth Edison; } \\
\text { unspecified amount for } \\
\text { renewable energy }\end{array}$ & TBD & TBD & TBD & $\begin{array}{l}\$ 6 \text { million purchase commitment } \\
\text { used to attract PV manufacturer } \\
\text { Spire Corporation to build a } \\
\text { photovoltaics manufacturing plant } \\
\text { on a redeveloped brownfield site on } \\
\text { the west side of Chicago }\end{array}$ \\
\hline $\begin{array}{l}\text { Minnesota } \\
\text { (Northern States } \\
\text { Power service } \\
\text { territory) }\end{array}$ & $\begin{array}{l}\$ 4.5 \text { million in } 1999 \text {, rising } \\
\text { to } \$ 8.5 \text { million annually by } \\
2003\end{array}$ & $\begin{array}{l}\text { Wind, solar, } \\
\text { biomass, and } \\
\text { run-of-river } \\
\text { hydro with } \\
\text { head of less } \\
\text { than } 66 \text { feet }\end{array}$ & $\begin{array}{l}\text { Grants for first } \\
\text { year, then grants, } \\
\text { production } \\
\text { incentives, } \\
\text { equity } \\
\text { partnerships, } \\
\text { loans and/or } \\
\text { revolving loan } \\
\text { fund }\end{array}$ & $\begin{array}{l}\text { Six-person board of } \\
\text { directors, with two } \\
\text { representatives from } \\
\text { Northern States } \\
\text { Power, two from } \\
\text { environmental } \\
\text { groups, and two from } \\
\text { consumer groups }\end{array}$ & $\begin{array}{l}\text { Preference for renewable electric } \\
\text { projects as opposed to R\&D and } \\
\text { commercialization; less preference } \\
\text { also given to renewable energy } \\
\text { projects that do not promote local } \\
\text { economic development or are not } \\
\text { yet commercially viable; projects } \\
\text { sponsored by the Prairie Island } \\
\text { Mdewankanton tribe may be given } \\
\text { preference; NSP may also propose } \\
\text { projects after the first year of the } \\
\text { fund's operation, including projects } \\
\text { to meet the wind and biomass } \\
\text { legislative mandates; all projects } \\
\text { must be approved by the Minnesota } \\
\text { PUC, and NSP retains right of first } \\
\text { refusal to purchase the electric } \\
\text { power from any funded projects }\end{array}$ \\
\hline $\begin{array}{l}\text { New York Fund } \\
\# 2 \text { (Long Island } \\
\text { Power } \\
\text { Authority) }\end{array}$ & $\begin{array}{l}\text { \$32 million over five years, } \\
\text { 1999-2003, for energy } \\
\text { efficiency, clean distributed } \\
\text { energy, and renewable } \\
\text { energy technologies }\end{array}$ & TBD & $\begin{array}{l}\text { Only funded } \\
\text { rebate program } \\
\text { for small PV } \\
\text { systems to date }\end{array}$ & $\begin{array}{l}\text { Long Island Power } \\
\text { Authority }\end{array}$ & $\begin{array}{l}\text { Created in May 1999; LIPA has } \\
\text { installed free PV systems on } \\
30 \text { homes }\end{array}$ \\
\hline $\begin{array}{l}\text { Pennsylvania } \\
\text { (PECO/Unicom } \\
\text { merger } \\
\text { settlement) }\end{array}$ & $\begin{array}{l}\$ 20 \text { million over five years: } \\
\$ 12 \text { million for wind, } \$ 4 \\
\text { million for PV, } \$ 2.5 \text { million } \\
\text { for education, and } \$ 1.5 \\
\text { million to extend "core" } \\
\text { PECO fund by } 18 \text { months; } \\
\text { another } \$ 3.5 \text { million goes } \\
\text { directly to Community } \\
\text { Energy to support its wind } \\
\text { development }\end{array}$ & Wind and PV & $\begin{array}{l}\text { Evaluating bids } \\
\text { for a } \$ 6 \text { million } \\
\text { wind production } \\
\text { incentive bid }\end{array}$ & $\begin{array}{l}\text { The Reinvestment } \\
\text { Fund ( } \$ 20 \text { million) } \\
\text { Community Energy } \\
\text { (\$3.5 million) }\end{array}$ & $\begin{array}{l}\text { Merger awaiting final regulatory } \\
\text { approval }\end{array}$ \\
\hline
\end{tabular}

